\title{
THE HERMITE-HADAMARD INEQUALITY FOR CONVEX FUNCTIONS OF A VECTOR VARIABLE
}

\author{
CONSTANTIN P. NiCULESCU
}

Abstract. The Hermite-Hadamard inequality is discussed in the light of Choquet's theory.

Mathematics subject classification (2000): Primary 26D07, 26D15, 46A55. Secondary 52A07. Key words and phrases: convex function, barycenter, extreme point.

\section{REFERENCES}

[1] E. M. AlFSEN, Compact convex sets and boundary integrals, Springer-Verlag, Berlin, 1971.

[2] C. E. M. PEARCE AND S. S. DRAGOMIR, Selected topics on Hermite-Hadamard Inequality and Applications, Victoria University, Melbourne, 2000.

[3] S. S. DRAGOMIR, On Hadamard's inequality for the convex mappings defined on a ball in the space and applications, Math. Inequal. \& Appl., 3 (2000), 177-187.

[4] A. M. FINK, A best possible Hadamard inequality, Math. Inequal. \& Appl., 1 (1998), 223-230.

[5] R. R. PHELPS, Lectures on Choquet's Theorem, D. van Nostrand Company Inc., Princeton, 1966. 